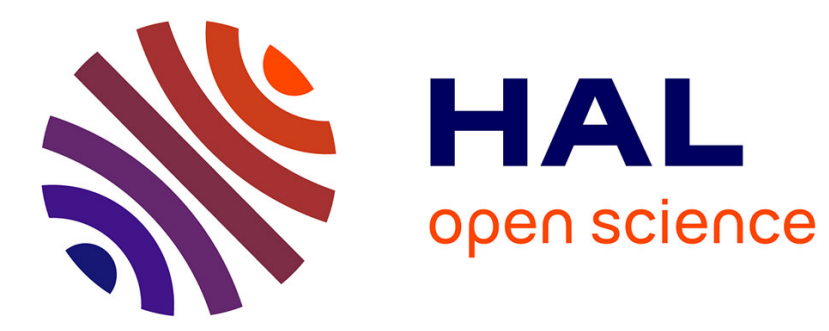

\title{
Dna adducts and polycyclic aromatic hydrocarbon (PAH) tissue levels in BLUE mussels ( spp.) from nordic coastal sites
}

Halldóra Skarphédinsdóttir, Gunilla Ericson, Jörundur Svavarsson, Kristoffer Næs

\section{To cite this version:}

Halldóra Skarphédinsdóttir, Gunilla Ericson, Jörundur Svavarsson, Kristoffer Næs. Dna adducts and polycyclic aromatic hydrocarbon (PAH) tissue levels in BLUE mussels ( spp.) from nordic coastal sites. Marine Environmental Research, 2007, 64 (4), pp.479. 10.1016/j.marenvres.2007.03.007 . hal00501915

\section{HAL Id: hal-00501915 \\ https://hal.science/hal-00501915}

Submitted on 13 Jul 2010

HAL is a multi-disciplinary open access archive for the deposit and dissemination of scientific research documents, whether they are published or not. The documents may come from teaching and research institutions in France or abroad, or from public or private research centers.
L'archive ouverte pluridisciplinaire $\mathbf{H A L}$, est destinée au dépôt et à la diffusion de documents scientifiques de niveau recherche, publiés ou non, émanant des établissements d'enseignement et de recherche français ou étrangers, des laboratoires publics ou privés. 


\section{Accepted Manuscript}

Dna adducts and polycyclic aromatic hydrocarbon (PAH) tissue levels in BLUE mussels (Mytilus spp.) from nordic coastal sites

Halldóra Skarphédinsdóttir, Gunilla Ericson, Jörundur Svavarsson, Kristoffer Næs

PII:

S0141-1136(07)00058-X

DOI:

10.1016/j.marenvres.2007.03.007

Reference:

MERE 3117

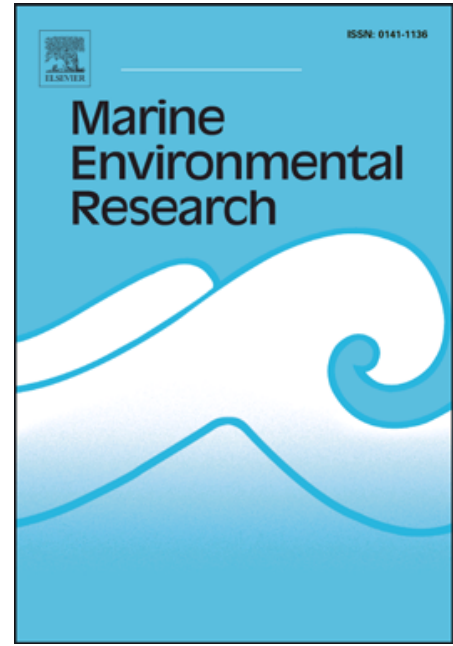

To appear in:

Marine Environmental Research

Received Date:

21 March 2007

Revised Date:

27 March 2007

Accepted Date:

27 March 2007

Please cite this article as: Skarphédinsdóttir, H., Ericson, G., Svavarsson, J., Næs, K., Dna adducts and polycyclic aromatic hydrocarbon (PAH) tissue levels in BLUE mussels (Mytilus spp.) from nordic coastal sites, Marine Environmental Research(2007), doi: 10.1016/j.marenvres.2007.03.007

This is a PDF file of an unedited manuscript that has been accepted for publication. As a service to our customers we are providing this early version of the manuscript. The manuscript will undergo copyediting, typesetting, and review of the resulting proof before it is published in its final form. Please note that during the production process errors may be discovered which could affect the content, and all legal disclaimers that apply to the journal pertain. 


\title{
DNA ADDUCTS AND POLYCYCLIC AROMATIC HYDROCARBON (PAH) TISSUE LEVELS IN BLUE MUSSELS (MYTILUS SPP.) FROM NORDIC COASTAL SITES
}

\author{
H ALLDÓRA SKARPHÉDINSDÓTTIR †*, GUNILLA ERICSON †,JÖRUNDUR SVAVARSSON \| AND \\ KRISTOFFER NÆS $§$
}

†The Department of Applied Environmental Science, Stockholm University, SE-106 91 Stockholm, Sweden || Institute of Biology, University of Iceland, Askja-Natural Science Building, 101 Reykjavík, Iceland $\S$ Norwegian Institute for Water Research, Southern Branch, Televeien 3, N-4879 Grimstad, Norway

* Corresponding author:

Halldora Skarphedinsdottir

Laboratory for Aquatic Ecotoxicology

Department of Applied Environmental Science

SE-106 91 Stockholm

Sweden

Tel: +4686747270

Mobile: +46 709791755

Fax: +46 86747638

E-mail: halldora@itm.su.se 


\begin{abstract}
DNA adducts in gills and digestive gland, as well as polycyclic aromatic hydrocarbon (PAH) tissue levels were analysed in blue mussels (Mytilus spp.) from Nordic coastal areas (Iceland, Norway and Sweden) with diffuse or point sources of PAHs of various origins. Both DNA adduct and PAH tissue levels were generally low, indicating low PAH exposure to the mussels in the areas studied. DNA adducts were found to be higher in gills than in digestive gland of the mussels at all sites studied Elevated DNA adduct levels in gills were found at 6 sites out of 18 compared to reference sites in respective coastal zones. Adduct levels ranged from 0.5 - $10 \mathrm{nmol}$ adducts/mol normal nucleotides, being highest in mussels from Reykjavík harbour, Iceland (intertidal mussels), and from Fiskaatangen, Norway (subtidal mussels). Total PAH tissue levels in the mussels ranged between 40 - 11670 ng/g dry wt., and were significantly correlated with DNA adduct levels $\left(\mathrm{r}^{2}=0.73 \mathrm{p}<0.001\right)$. PAH ratio values indicated that the PAHs were in most cases of pyrolytic origin, but with petrogenic input near harbours and an oil refinery.
\end{abstract}

Keywords: DNA adducts, Genotoxicity, Biomarker, Polycyclic aromatic hydrocarbons, Mytilus spp., Field study, Nordic coastal waters 


\section{INTRODUCTION}

Among the variety of natural and anthropogenic contaminants in the aquatic environment there are many that are genotoxic, i.e. capable of interacting with the genetic material. For example, polycyclic aromatic hydrocarbons (PAHs) have well documented toxic, mutagenic and carcinogenic properties, which along with the fact that they are widely distributed in the environment, makes them priority pollutants (Neff, 1979). PAHs derive from incomplete combustion of fossil fuels, creosote production, discharges from electrochemical industry such as aluminium smelters, and oil spills (Lorenz and Glovik, 1972; Neff, 1979).

PAHs are for example known to cause genetic toxicity through the formation of DNA adducts. DNA adducts are produced by the formation of cova lent bonds between a genotoxic chemical or its metabolite and the DNA molecule (Miller \& Miller, 1981). Damaged DNA that is not repaired in time may have direct consequences like cell death, tumour initiation, embryo toxicity, mutations or other dysfunctions (Shugart, 1995; Kurelec, 1993). Analysis of

DNA adducts by the ${ }^{32} \mathrm{P}$-postlabelling method has in many field studies on fish been confirmed as a sensitive and reliable biomarker of exposure to and effects of PAHs (e.g. Stein et al., 1993; Reichert et al., 1998; Ericsson et al., 1999). DNA adduct formation and analysis in marine Mytilid bivalve mussels has recently received increasing attention. Mussels have less active enzyme system than fish for biotransformation of xenobiotics, but they do possesses the metabolic capacity to activate potentially genotoxic compounds to reactive intermediates capable of binding to DNA (e.g. Livingstone et al., 1984; Harvey and Parry, 1997). Experimental studies have shown that Mytilid mussels form DNA adducts following exposure to PAHs, amines and nitro aromatic substances (e.g. Marsh et al., 1993; Venier and Canova, 1996; Harvey and Parry, 1997; 1998; Akcha et al., 2000; Skarphedinsdottir et al., 2003). Field studies on DNA adduct levels in Mytilids are few (Kurelec, 1990; Venier et al., 
1996; Sole et al., 1996; Harvey et al., 1997; Harvey et al., 1999; Ericson et al., 2002;

Skarphedinsdottir et al., 2005), although mussels are important components of the coastal ecosystems and are in many ways ideal bioindicator organisms.

In this study the objective was to i) study and characterise DNA adduct levels in blue mussels (Mytilus spp.) as well as PAH mussel tissue levels from Nordic coastal waters with different PAH pollution loads, ii) to investigate which tissue, gills or diges tive gland, had the highest adduct levels and iii) to see if DNA adduct values correlated with PAH tissue levels. The sites chosen for this study were sites suspected to have various PAH origins, mixtures and levels, such as harbours of different sizes, industrialised and urban sites, as well as unpolluted sites for reference.

\section{MATERIALS AND METHODS}

\section{Chemicals}

Salmon sperm DNA (S-1626), spermidine (S-2626), dithiothreitol (D-9779), RNase A (R 4642), micrococcal endonuclease (N-3755), spleen phosphodiesterase (P-9041) and polyethylenimine (P3143) were obtained from Sigma-Aldrich Sweden AB, Stockholm, Sweden. Proteinase K (1000144), $\alpha$-amylase (102814), RNase T 1 (109 193), nuclease P1 (236 225), T4 polynucleotide kinase (3'phosphatase-free, 838 292) and phenol (1814303) were supplied by Roche Diagnostics Scandinavia AB, Sweden. $\left[\gamma^{32} \mathrm{P}\right] \mathrm{ATP}$ was obtained from Amersham Pharmacia Biotech (now General Electric healthcare), Uppsala, Sweden, and cellulose (MN 301) from Tamro MedLab AB, Mölndal, Sweden. The standard adduct 7R, 8S, 9S-trihydroxy, 10R- ( $\mathrm{N}^{2}$-deoxyguanosyl-3'-phosphate)-7, 8, 9, 10-tetrahydro-benzo[a]pyrene 
(BaPDE-dG-3’p) was obtained from NCI Chemical Repository, Midwest Research Institute, Kansas City, Missouri, USA. All other chemicals used were of analytical grade or higher.

Sampling sites

Blue mussels (Mytilus spp.) were collected from 22 different coastal sites in Iceland, Sweden and Norway in October 2000. The sampling sites are indicated in Figure 1 and described in Table 1. The sites chosen were harbours of different sizes and industrialised/ urban sites with suspected or already documented PAH contamination in bottom sediments or organisms, and reference sites without any site -specific pollution.

In Sweden, blue mussels (Mytilus spp.) were collected at 5 sites along the east coast; the brackish Baltic Sea, and Mytilus edulis was sampled at 6 sites along the west coast; in Skagerrak. Askö represents a reference site in the Baltic Sea, and the site Fjällbacka, which has been used as a reference site in field investigations of pollutant levels and effects on fish, represents the reference site on the Swedish west coast. The other Swedish sites were chosen due to their close location to industries, i.e. Oxelösund (steel plant), Svartören and Svartlingskär (pulp industry), Stenungsund (petrochemical industry), Brofjorden (oil refinery) or heavily urbanised areas such as Göteborg (Gothenburg), where one of the sampling sites is located close to the mouth of the river Göta älv along which several industries and harbours are located. In Sweden the tidal water range is $\sim 0.2 \mathrm{~m}$ on the west coast, but on the east coast in the Baltic Sea, it is practically zero. Average sea temperature and salinity for October 2000 at the Swedish west coast sites were $\sim 13^{\circ} \mathrm{C}$, and $\sim 24 \%$, and for the Baltic Sea sampling sites, $10-11^{\circ} \mathrm{C}$, and 6-7\%o (Based on data provided by the Swedish Meteorological and Hydrological Institute (SMHI), Stockholm Marine Research Centre (SMF) and HavsFiskeLaboratoriet in the frame of the Swedish Environmental Monitoring Programme). 
Along the Norwegian coast, blue mussels (Mytilus edulis) were collected at 4 different sites, i.e. at Croftholmen, Valløy, Fiskaatangen, and Sauda. Three of the stations (Croftholmen, Valløy, Fiskaatangen) are at the southern part of Norway along the Skagerrak Sea, while Sauda is located in an inner part of a fjord at the western coast of Norway. Croftholmen, Fiskaatangen, and Sauda represent areas with PAH point sources. Croftholmen is located in Norway's most industrialised area and influenced both by heavy merchant ship traffic and effluents from a manganese smelter. The same apply to the samples from Fiskaatangen (anode plant for manganese smelters and commercial harbour) and Sauda (manganese-alloy production). Valløy represents the reference site, it is located in open coastal waters with no specific point source. The tidal water range is $\sim 0.6 \mathrm{~m}$ at Crofholmen, Valløy and Fiskaatangen, and $\sim 0.8 \mathrm{~m}$ at Sauda. Sea temperature was measured at the sites and ranged from $12-14^{\circ} \mathrm{C}$. Salinity at Croftholmen is in average $\sim 25 \%$, and $\sim 30-33 \%$ at Fiskaatangen, Sauda and Valløy (Based on data from the Norwegian Mete orological Institute).

In Iceland, blue mussels (Mytilus edulis) were collected at the reference site Hvalfjörður, and at 6 sites close to or in harbours with supposed different levels of pollution along the south-western and western coast of Iceland. The sites were Reykjavík harbour, Grafarvogur (urban area of Reykjavík), Keflavík harbour, Porlákshöfn harbour, Ólafsvík harbour, and Ísafjörður (close to a small town and a harbour). The sampling site in Reykjavík is in the old harbour, which is the largest harbour in the country, with intense traffic of small and large vessels. This site was supposed to have the highest marine pollution levels in Iceland. The sampling sites in Keflavík, Porlákshöfn and Ólafsvík are in small fishing harbours, with supposed intermediate pollution. Grafarvogur is an urban area, situated 5 kilometres east of the cargo harbour in Reykjavík, a site with supposed intermediate to low pollution levels. The sampling site at Ísafjörður is situated $2 \mathrm{~km}$ from the small fishing harbour in Ísafjörður town, 
with supposed low pollution levels. The reference site Hvalfjörður is situated in a fjord about $60 \mathrm{~km}$ from Reykjavík. Mussels from this site have been analysed on a yearly basis within a monitoring program, with results indicating low levels of contaminants. The tidal water range in Iceland is $\sim 3.8 \mathrm{~m}$ at Reykjavík, Grafarvogur og Hvalfjörður; $\sim 3.7 \mathrm{~m}$ at Keflavík, Porlákshöfn and Ólafsvík; and 2.1m at Ísafjörður. Average s ea temperature at these sites in October 2000 was $7-8^{\circ} \mathrm{C}$, and salinity $3435 \%$ (based on data provided by The Marine Research Institute in Iceland).

\section{Mussels sampled}

The mussels sampled were adult Mytilus edulis ranging from $46 \mathrm{~cm}$ in size, except for mussels from the Baltic Sea. Baltic Sea mussel populations may contain mussels with a significant proportion of Mytilus trossulus genotypes, which are not easily distinguished from Mytilus edulis, so here the Baltic Sea mussels are referred to as Mytilus spp.. No individuals with pure M. trossulus genotypes have been found in the Baltic Sea, but M. trossulus alleles are maintained at high frequencies for some allozyme genes (Riginos and Cunningham, 2005). The Baltic Sea mussels have small sizes at maturity, which mostly appears to be a consequence of living in a low salinity environment, and they reach a maximum of $1 / 3$ that of North Sea mussels (e.g. Kautsky 1982). The Baltic Sea mussels sampled here were adult mussels ranging from $2-3 \mathrm{~cm}$, which is as large as they get in this area.

There were differences in where from the coastal zone the mussels were sampled. Icelandic mussels were sampled in the intertidal zone at low tide from the shoreline, but in Norway and Swedenwhere the intertidal range is considerably smaller, the mussels were sampled from just below the tidal range; in the subtidal zone. Swedish mussels were sampled by hand from the shore at $0.5-1 \mathrm{~m}$ depth, and the Norwegian ones at $\sim 1 \mathrm{~m}$ depth by diving. This means that the Icelandic mussels sampled were such that are exposed to tidal waters and 
the others not. The Swedish and Norwegian mussels are however from shallow waters, and therefore affected by wind and waves, and thus exposed to the surface, although more irregularly, and for shorter periods of time than mussels in the intertidal zone.

\section{Sample preparation}

From each sampling site 20 mussels were sampled for DNA-adduct analysis and 25 mussels for analysis of PAHs. After collection, the intestinal canal of the mussels for PAHanalysis were cleaned by keeping them in nets for 24 hours in containers with seawater from the respective sample sites. The temperature was at ambient conditions. The mussels were then frozen for subsequent PAH tissue analysis. Mussels for DNA adduct analysis were transported moist and cold to the laboratory where gills and digestive glands were dissected out and snap frozen in liquid nitrogen. Tissues from five mussels were pooled and ground into a fine homogenous powder in liquid nitrogen by use of a pre-cooled mortar and pestle. An aliquot of the homogenates were used for DNA-extraction. Four pools of tissues were analysed from all sites.

\section{DNA adduct analysis}

DNA was extracted from tissue samples and purified essentially as described by Reichert and French (1994). For a detailed description see Skarphedinsdottir et al. (2003). DNA adducts were analysed with the nuclease $\mathrm{P}_{1}$ version of the ${ }^{32} \mathrm{P}$-postlabelling method as described in Reichert and French (1994), with some modifications. Briefly, aliquots of $12.5 \mu \mathrm{g}$

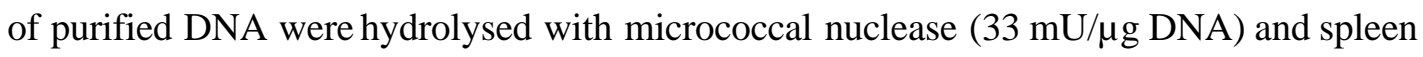
phosphodiesterase (3.2 mU/ $\mu \mathrm{g}$ DNA) at $\mathrm{pH} 6.0$ in incubation for 4 hours at $37^{\circ} \mathrm{C}$. After adjustment of the $\mathrm{pH}$ to 5.0, normal nucleotides were hydrolysed to nucleosides by adding $0.5 \mu \mathrm{g}$ Nuclease $\mathrm{P}_{1} / \mu \mathrm{g}$ DNA and incubating at $37{ }^{\circ} \mathrm{C}$ for $30 \mathrm{~min}$. After adjustment of $\mathrm{pH}$ to 
approximately 7.8, the mixture was evaporated to dryness in a SpeedVac ${ }^{\circledR}$ (Savant). Labelling of adducts was performed by adding a mixture contain ing 5 units of T4 polynucleotide kinase, 3.1 MBq $\left[\gamma_{-}{ }^{32} \mathrm{P}\right]$-ATP $(110 \mathrm{TBq} / \mathrm{mmol}), 50 \mathrm{mM}$ Tris base, $10 \mathrm{mM} \mathrm{MgCl} 2,10 \mathrm{mM}$ dithiothreitol and $5 \mathrm{mM}$ spermidine at $\mathrm{pH}$ 7.6. Incubation lasted for 30 minutes at $37^{\circ} \mathrm{C}$. Labelled adducts were separated by multidirectional chromatography on laboratory prepared polyethyleneimine cellulose thin layer sheets. Chromatography solvents used for the separation were 1.0 M sodium phosphate at pH 6.0 (D1), 7.25 M urea, 3.86 M lithium formate at $\mathrm{pH} 3.5$ in the opposite direction of D1 (D3), 7.25 M urea, 0.42 M Tris-HCL, 1.36 M lithium chloride at $\mathrm{pH} 8.0$ perpendicular to D3 (D4) and $1.0 \mathrm{M}$ sodium phosphate at $\mathrm{pH} 6.8$ in the same direction as D4 (D5). A PhosphorImager (Molecular Dynamics), was used for detection of the ${ }^{32} \mathrm{P}$-postlabelled adducts, and the radioactive spots on the autoradiograms were quantified and converted to digital pixels values with ImageQuant computer software (Reddy and Randerath, 1986).

Three different control samples were run in parallel with all samples: 1) DNA adducted liver tissue from perch liver exposed in vivo to benzo[a]pyrene was used as a positive control, processed parallel with the samples to ensure against inter-assay variation, 2) The standard adduct (BaPDE-dG-3'p) was used as a control of labelling efficiency and the chromatographic system, and 3) salmon sperm DNA as a negative control to ensure that no artefacts or false adducts appeared.

\section{Chemical workup and analysis of PAHs in mussel tissue}

A total of 32 PAHs were analysed: Naphthalene, 2-methyl-naphthale ne, 1-methylnaphthalene, biphenyl, 2,6-dimethyl-naphthalene, 1,6-dimethyl-naphthalene, 1,5-dimethylnaphthalene, acenaphthylene, acenaphthene, 2,3,6-trimethyl-naphthalene, 2,3,5-trimethylnaphthalene, 1,2,4-trimethyl-naphthalene, fluorene, 1,2,3-trimethyl-naphthalene, 
dibenzothiophene, phenanthrene, anthracene, 2-methyl-phenanthrene, 1-methyl-phenanthrene, 3,6-dimethylphenanthrene, fluoranthene, 9,10-dimethyl-phene, pyrene, benz[a]anthracene, chrysene+triphenylene, benzo $[\mathrm{b}+\mathrm{j}, \mathrm{k}]$ fluoranthene, benzo[e]pyrene, benzo[a]pyrene, perylene, indeno[1,2,3cd]pyrene, dibenz[a,c/a,h]anthracene, benzo[ghi]perylene. From each location a homogenized sample conta ining soft tissue of 25 individual mussels was prepared. Internal standards were added (deuterated naphthalene, acenapht hene, phenanthrene, chrysene and perylene) to the homogenate and the mixture was saponified. The PAHs were extracted with n-pentane and dried over sodium sulphate. The extraction volume was reduced, solvent exchanged to DCM (dichloromethane), and the extracts were cleaned using gel permeation chromatography (GPC) and solvent was exchanged to cyclohexane. If necessary, the samples were further cleaned by DMF (dimethylformamide) partitioning and silica column elution. The extracts were analysed by GC/MS. The MS detector was operated in selective ion monitoring mode (SIM), and the analyte concentrations in the standard solutions were in the range 5-1000 ng/ $\mu \mathrm{l}$. The GC was equipped with a $30 \mathrm{~m}$ column with a stationary phase of $5 \%$ phenyl polysiloxane ( $0.25 \mathrm{~mm}$ i.d. and $0.25 \mu \mathrm{m}$ film thickness), and an inlet operated in the splitless mode. The initial column temperature was $60^{\circ} \mathrm{C}$, which after two minutes was raised to $250^{\circ} \mathrm{C}$ at a rate of $7^{\circ} \mathrm{C} / \mathrm{min}$ and thereafter raised to $310^{\circ} \mathrm{C}$ at a rate of $15^{\circ} \mathrm{C} / \mathrm{min}$. The injector te mperature was $300^{\circ} \mathrm{C}$, the transfer line temperature was $280^{\circ} \mathrm{C}$, the MS source temperature was $230^{\circ} \mathrm{C}$ and the column flow rate was $1.2 \mathrm{ml} / \mathrm{min}$. Internal standards are used for quantification. Standard reference material SRM 2260 from National Institute of Standards and Technology (NIST) has been used for GC-calibration and the relative accuracies have been controlled against SRM 2977. The detection limits depend on sample amount, final extract volumes and instrument conditions. Normally they are $0.5 \mu \mathrm{g} / \mathrm{kg}$ wet weight. 


\section{Statistical analysis}

DNA adduct levels were compared statistically with levels from each reference site by one-way ANOVA and Newman-Keuls, and Dunnett post hoc test. Relationships between PAHs and DNA adducts were studied with regression analysis, all values were transformed when necessary after checking for normality and homogeneity of the variances. The software used for statistical analysis was Statistica 5.5 (by Statsoft Inc.).

\section{RESULTS}

\section{DNA adduct levels}

DNA adduct levels are presented in figure 2, and DNA adduct levels in gills are also shown in table 1 . The levels were higher in gills than in digestive gland of the mussels at all sites. The DNA adducts were generally low, or ranging from below the detection limits to 10 nmol adducts/mol normal nucleotides in gills of the subtidally sampled mussels at Fiskaatangen, Norway (harbour and industrial site), and in intertidal mussels at Reykjavík harbour, Iceland. The detection limits are different for each sample, depending on background of the autoradiograms, but calculated average and stdev of detection limits of all the autoradiograms here was $0.43 \pm 0.19 \mathrm{nmol}$ DNA adducts/ mol norm nucleotides. DNA adduct levels were significantly elevated in gills of mussels at 6 out of 18 sites compared to reference sites in respective coastal zones. These sites were Fiskaatangen (harbour and industrial site) and Croftholmen (industrial site) in Norway; Reykjavík harbour, Grafarvogur (urbanised) and Porlákshöfn harbour in Iceland; and Gothenburg (urbanised and harbours), west coast of Sweden. Digestive gland adduct levels were significantly elevated compared to reference sites 
at Svartlingsskär (pulp industry), Swedish (east coast) Baltic Sea, Fiskaatangen, Norway, and Reykjavík harbour in Iceland.

The adduct spots on the autoradiograms from gill samples exhibited similar pattern, a diagonal zone on the autoradiograms typical of PAH exposure, see figure 3. Fewer and much fainter adduct spots were observed on autoradiograms from the digestive glands (not shown).

\section{PAH tissue levels}

Total PAH tissue levels ( $\Sigma 32$ PAHs) are given in table 1. The total PAH tissue levels ranged from 10 - $11670 \mathrm{ng} / \mathrm{g}$ dry wt. mussel. The most contaminated mussels were those sampled in the harbours of Reykjavík (11670) and Ólafsvík (10830 ng/g dry wt.), Iceland. Total sum of 4-6 aromatic ring PAHs was highest in Fiskaatangen, Norway (3410 ng/g dry wt.), and Reykjavík harbour, Iceland, which are also the sites that had the highest DNA adduct levels. Total PAH and gill DNA adduct levels were significantly correlated $\left(r^{2}=0.73\right.$ $(\mathrm{n}=21, \mathrm{p}=0.002)$. If individual PAHs are studied, then phenanthrene and pyrene correlated individually best with the DNA adduct levels, with $\mathrm{r}^{2}=0.78(\mathrm{p}<0.001)$ and $0.71(\mathrm{p}<0.001)$ respectively. Highest correlation value for a group of compounds was found if the sum of the 4 PAHs 1,6-dimethylnaphthalene, 1,2,4-trimethylnaphthalene, phenanthrene and pyrene was correlated with DNA adducts; $\mathrm{r}^{2}=0.78(\mathrm{p}<0.001)$. The site Ólafsvík harbour in Iceland is excluded from correlation calculations since it is considered an outlier in this dataset, with very high PAH levels (mainly small PAHs) but relatively low DNA adduct levels.

\section{DISCUSSION}

\section{DNA adduct levels}


The mussel gill DNA adduct levels reported here from Icelandic sites are in the same range as our previous results on adduct levels in mussels collected from the intertidal zone in Iceland. DNA adduct levels in gills of mussels from Reykjavík harbour were found to be 10.3 nmol/mol norm. nucleotides in August 2000 (Ericson et al, 2002), and little lower or 5.9 nmol/mol norm. nucleotides in October 2001 (Skarphedinsdottir et al., 2005) compared to $10.0 \mathrm{nmol} / \mathrm{mol}$ nucleotides in this study (October 2000). Higher adduct levels have been found in mussels in winter at the same site; $18.9 \mathrm{nmol} / \mathrm{mol}$ nucleotides in March 2000, and 14.5 in March 2002, which is explained by seasonal variation in native mussels (Ericson et al., 2002; Skarphedinsdottir et al., 2005). Levels in Grafarvogur and Keflavík, Iceland in August 2000 in an earlier study were found to be 4 and $1.5 \mathrm{nmol} / \mathrm{mol}$ nucleotides respectively, or similar to our now (October 2000) observed 3.0 and $1.9 \mathrm{nmol} / \mathrm{mol}$ nucleotides. Differences in PAH and DNA adduct levels have been demonstrated between intertidal and subtidal mussels, which is important to bear in mind when evaluating and comparing adduct levels in mussels from different areas. The DNA adduct levels were found to be higher in intertidal mussels than in subtidal mussels, with a difference ranging from a factor of 1.3 - 2.9 (Skarphedinsdottir et al., 2005). Since the present study was conducted prior to these findings, depth was not taken into consideration in the sampling of the mussels. The Icelandic mussels here were sampled from the intertidal zone, which can be as large as 3. $8 \mathrm{~m}$, but the Swedish and Norwegian mussels from just below the considerably narrower intertidal zone in those areas (see methods). The Swedish and Norwegian mussels are however from shallow waters, and therefore affected by wind and waves, and exposed to the surface like the Icelandic mussels, although more irregularly, and for shorter periods of time. But because of these differences, the sites should preferably only be compared with their respective reference site. 
Other field studies on DNA adducts in mus sels are scarce. Kurelec et al. (1990) found elevated adduct levels in juvenile $M$. galloprovincialis near an oil refinery, but not in adult mussels from polluted sites in the northern Adriatic. Harvey et al. (1997) report 6.1 adducts $/ 10^{8}$ nucleotides (tissue not specified) (corresponding to $61 \mathrm{nmol} / \mathrm{mol}$ nucleotides) in M. edulis, analysed with the nuclease $\mathrm{P}_{1}$ enhancement method, from sites in Wales, UK. Harvey et al. (1999) studied genotoxic impact of the release of 72,000 tonnes of crude oil from grounding of the Sea Empress oil tanker in Wales, UK, but found no DNA adducts in $M$. edulis 2 and 11 months after the oil spill incident. Soft tissue of whole mussels were analysed for DNA adducts in that study, meaning that if DNA adducts were formed in gills or the digestive gland but not in other tissues, they would appear very diluted. DNA adducts were on the other hand elevated in vertebrates sampled in the area, at least 2 months after the oil spill. Solé et al. (1996) detected DNA adducts ranging from 0.20 to as much as 128 adducts $/ 10^{8}$ nucleotides (corresponding to $1280 \mathrm{nmol} / \mathrm{mol}$ nucleotides) in digestive gland of M. edulis sampled on the Galician coast at industrial and urban sites. Venier et al. (1996) analysed DNA adducts in gills of $M$. galloprovincialis from different sites of the Venice lagoon, and found adduct levels ranging from $0.009-0.346$ adducts $/ 10^{8}$ nucleotides (corresponding to 0.09 $3.46 \mathrm{nmol} / \mathrm{mol}$ nucleotides), which is more in the range of our results. When comparing DNA adduct levels between studies and different laboratories, it is however important to keep some facts in mind. Firstly the fact that DNA adduct levels in mussels are affected by tidal waters, so differences in where from the shoreline the mussels are sampled matter (Skarphedinsdottir et al., 2005). Secondly, the ${ }^{32} \mathrm{P}$-postlabelling assay is only a semi-quantitative method. $100 \%$ labelling efficiency and adduct resistance to the nuclease $\mathrm{P}_{1}$ treatment is assumed, and depending on the elution system and the hydrophobicity of the adducts, some adducts may be retained at the origin on the TLC sheets, and some washed away and thus not detected. Small 
differences in the assay protocol at different laboratories may thus lead to different levels of adducts (Ericson et al., 1998).

Studies on fish from contaminated sites in Nordic coastal areas have generally revealed higher DNA adduct levels than those observed in the mussels in this study, as is to be expected since fish have more active biotransformation system. Several studies on DNA adducts in fish at contaminated sites in the Swedish Baltic Sea have been reported. For example, adduct levels in liver of perch (Perca fluvatilis) and pike (Esox lucius) in a PAH gradient from an aluminium smelter in the vicinity of the city Sundsvall in the northern part of Swedish Baltic Sea coast ranged from 0.1 - 29 and 3.3 - $13.5 \mathrm{nmol} / \mathrm{mol}$ nucleotides respectively (Ericson, et al., 1998). Liver of perch from creosote contaminated site in the river Ångermanälven flowing into the Baltic Sea had up to $6.8 \mathrm{nmol}$ adducts/mol (Ericson, et al.,1999), and liver of perch sampled in the receiving waters of a bleached pulp mill at Norrsundet on the Baltic Sea coast had up to 22 nmol adducts/mol nucleotides (Ericson \& Larsson, 2000). The shorthorn sculpin (Myoxocephalus scorpius), sampled in 4 harbours of different sizes at the south-west coast of Iceland had up to $32 \mathrm{nmol}$ adducts/mol nucleotides in the liver of fish sampled in the fishing harbour of Sandgerði. Fish sampled in Reykjavík harbour had 23 nmol adducts/mol nucleotides in the liver (Stephensen, et al., 2000), compared with 10.0 in gills of blue mussels from same site in this study. Atlantic cod (Gadus morhua) and corkwing wrasse (Symphodus melops) caught in the receiving waters of an aluminium works in the Karmsund strait, Norway, revealed up to $27 \mathrm{nmol} / \mathrm{mol}$ nucleotides and 239 nmol/mol nucleotides respectively at the most contaminated site (Aas, et al., 2001).

The observed higher DNA adduct levels in gills than in digestive gland are in agreement with our earlier field results (Ericson et al., 2002), and experimental work (Skarphedinsdottir et al. 2003) with blue mussels, where adduct levels have been higher in gills in all cases. Many DNA adduct studies in mussels have focused on the digestive gland, but some 
researchers have studied other tissues such as the gills as well. Harvey and Parry (1997) also reported higher adduct levels in gills of M.edulis than in digestive gland after experimental exposure to genotoxic compounds. Results on DNA adduct formation in the close ly related species M. galloprovincialis are however somewhat contradictory; show either no marked differences in adduct levels between these tissues (Canova et al., 1998), or higher BaP-DNA binding in the digestive gland than gills (Akcha et al., 1999). It is possible that the gills are exposed to higher PAH levels through direct absorption into gills from the water phase compared to absorption of PAHs adsorbed to small particles that are taken up via the digestive system. Our experimental work shows however that when exposed to BaP, the mussels accumulate higher BaP levels in the digestive gland, but more DNA adducts are however formed in the gills (Skarphedinsdottir, 2003). The DNA adduct formation is dependent upon the balance between activating (phase I) and detoxifying (phase II) enzymatical processes in the cell, which may vary between tissues. It is thus possible that detoxification of primary metabolites is more effective in digestive gland than in gills of blue mussels or that the digestive gland is more efficient in DNA repairs than gill tissues. Further studies on enzymatical processes in different tissues are needed to elucidate if these are possible explanations for the observed tissue differences in DNA adduct formation in the blue mussel.

\section{PAH tissue levels}

The PAH mussel tissue levels in this study are comparable with earlier studies on polluted and clean sites in same or neighbouring areas. Broman et al., (1990) reported $\Sigma 19$ PAHs in mussel tissue sampled on the Swedish coast of the Baltic Sea to be $443 \mathrm{ng} / \mathrm{g}$ dry wt. Baumard et al., (1999) analysed $\Sigma 18$ PAH tissue levels in blue mussels sampled near the German coast in the south-west Baltic Sea close to point sources and further out to sea. The levels ranged 
between 90 - 3900 ng/g dry wt., or little higher if compared to our $\Sigma 32$ PAH levels of 40 $1330 \mathrm{ng} / \mathrm{g}$ dry wt. in mussels sampled on the Swedish coast of the Baltic Sea. Mussels from mouth of rivers in the Pomeranian Bay and the Gulf of Gdansk in the southern Baltic Sea had PAH levels of 9 - 30 ng/g wet wt. (Potrykus, et al., 2003), compared to 9 - 105 ng/g wet wt. in the Baltic Sea in this study. Granby and Spliid (1995) reported $\Sigma 14$ PAHs in mussels sampled from 25 non point source sites on the Danish coast in the Kattegat in the North Sea, and the belts to be $10-111 \mathrm{ng} / \mathrm{g}$ wet wt., or similar if compared with our $12-91 \mathrm{ng} / \mathrm{g}$ wet wt. in mussels although they are sampled from both supposed clean and suspected polluted sites on the Swedish west coast in the Skagerak in the North Sea. Normal background PAH tissue levels in mussel in Norway is reported to be up to $300 \mathrm{ng} / \mathrm{g}$ dry wt. and less in more remote areas, but up to as much as 1000 times the background values have been found within outfalls of industries, such as smelter discharges. PAH tissue le vels in blue mussels from the contaminated Saudafjord have for example been found to range from 8300 - $1729000 \mathrm{ng} / \mathrm{g}$ dry wt. (Næs et al., 1995), compared to $720-5120 \mathrm{ng} / \mathrm{g}$ dry wt. in Norwegian mussels in this study. PAH tissue levels in blue mussels transplanted to the intertidal zone in Reykjavík harbour 2001 ranged from 9949 - 114294 ng/g lipid weight (corresponding to 845 - 9715 ng/g dry wt.) with maximum levels in winter, and minimum levels in spring and summer (Ska rphedinsdottir, et al. 2005).

Mussel PAH tissue levels from other locations for comparison are for example $8-341$ wet wt. in M. edulis sampled at both diffuse and point sources at coastal locations in Scotland, and 15 - 7200 ng/g wet wt. from Shetland and Orkney (Webster et al., 2003) (compared with our 3 - 1559 ng/g wet wt. at all locations). Solé (2000) reported PAH tissue levels in mussels from pollution gradients from harbours in the Mediterranian coast, Venice lagoon ( $M$. galloprovincialis), Galician coast, and the North Sea (M.edulis) to be 19-2675, 17-139, 22 270, and 416 ng /g wet wt. respectively. Baumard et al., (1998) studied levels of 14 PAHs in 
M galloprovincialis from 10 remote and polluted sites of the Mediterranian coasts of Spain and France, and found them to range from from 25-337 ng/g dry wt. Porte et al., (2001) reported also PAH levels in M. galloprovincialis from a pollution gradient on the Galician coast (NW Spain), which were found to be 22 - 562 ng/g wet wt. Mussels from western Greenland contained 497 ng/g dry wt. (Pecseli et al. 2002). In general, our PAH levels seem correspond to the less and moderately polluted areas of Europe.

Comparison of mussel pollutant tissue levels between studies should however be practiced with caution, since many factors affect the pollution tissue levels, such as intertidal impact, seasonal variation in filtering rates, reproduction and lipid levels. Filtering rates are higher during spring and autumn algae bloom, which induces greater exposure to comtaminants, and spawning in spring/ summer releases lipids as well as hydrophobic contaminants (Gosling, 1992).

Of individual PAHs, phenanthrene and pyrene correlated individually best with the DNA adduct levels, with $\mathrm{r}^{2}=0.78(\mathrm{p}<0.001)$ and $0.71(\mathrm{p}<0.001)$ respectively, and highest correlation value for a group of compounds was found if the sum of the 4 PAHs 1,6dimethylnaphthalene, 1,2,4-trimethylnaphthalene, phenanthrene and pyrene was correlated with DNA adducts; $\mathrm{r}^{2}=0.78(\mathrm{p}<0.001)$. Most of the DNA adduct and PAH tissue levels in this study are low, and higher values are actually needed for more reliable correlation calculations and interpretation of the relationship between DNA adducts and tissue levels. The ${ }^{32} \mathrm{P}-$ postlabelling method used here for analysing the DNA adducts, with the nuclease $\mathrm{P}_{1}$ version and standard elution system, is traditionally considered to detect mainly large hydrophobic aromatic (4-6 ring) DNA adducts. Therefore, the smaller PAHs (like naphthalene) are probably not contributing directly to the DNA adduct levels. They could however affect the levels indirectly, e.g. by inducing the bioactivating system and in that way possibly leadto higher levels of larger DNA-reactive intermediates. 
The relationship between PAH tissue levels and its genotoxic effects as seen in DNA adducts is also complicated by several factors. PAHs have to be metabolised to form DNA adducts in organisms, so the parent compound is no longer measurable when its reactive metabolite exerts its genotoxic effects by binding to DNA and forming adducts. Organisms are also known to accumulate and biotransform compounds selectively. For example, benzo[e]pyrene has been observed to be preferentially accumulated relative to benzo[a]pyrene by M. edulis (Baumard 1999) and M. galloprovincialis (Baumard et al. 1998). This has been related to selective biotransformation of $\mathrm{B}[\mathrm{a}] \mathrm{P}$, while $\mathrm{B}[\mathrm{e}] \mathrm{P}$ is preferentially accumulated in the lipids. Benzo[a]pyrene has also been shown to be more genotoxic than benzo[e]pyrene), so the higher $\mathrm{B}[\mathrm{e}] \mathrm{P}$ values could be attributed to a preferential biotransformation of $\mathrm{B}[\mathrm{a}] \mathrm{P}$ to more reactive and genotoxic metabolites.

\section{Origin of the PAHs}

Mussels sampled in or close to harbours had relatively higher levels of lower molecular weight PAHs, while mussels sampled close to industrial areas had higher levels of larger PAHs. Ratios between individual PAH compounds have also been used as a way of indicating the processes from which PAHs originate. PAHs are generated by three main processes: Combustion at high temperature of organic matter, release of pe troleum, and degradation of organic matter (Neff, 1979). Phenanthrene/Anthracene (Phe/Ant) and Fluorene/Pyrene (Fl/Pyr) ratios are commonly used as a mains of determining the dominant origins of PAHs (Colombo et al., 1989; Budzinski et al., 1997). Pyrolysi of organic matter at high temperatures generates PAHs characterised by low Phe/Ant ratio $(<10)$, while the slow maturation of petroleum at lower temperatures leads to larger values of the Phe/Ant ratio (> 25) (Baumard et al., 1999). Fluoranthene and Pyrene are often associated and considered typical pyrogenic products generated from high temperature condensation of low molecular 
weight compounds (Soclo et al., 2000). During the combustion process pyrene is more stable than fluoranthene, so pyrolytic products are usually characterised by a predominance of fluoranthene over pyrene at ratios $>1$ (Baumard et al., 1999). So $\mathrm{Ph} / \mathrm{An}>10$ and $\mathrm{Fl} / \mathrm{Pyr}<1$ indicates petrogenic origin of the PAHs, while the opposite indicates pyrogenic origin.

The Phe/Ant and Fl/Pyr ratio values in this study (see table 1) indicated that the PAHs were in most cases of pyrolytic origin, but with input of petrogenic hydrocarbons close to harbours and the oil refinery (indicated by Fl/Pyr ratios) as seen in the Icelandic mussels sampled in or close to harbours, in mussels sampled in Gothenburg, Swedish west coast (river mouth; urbanised and harbours), and in Brofjorden, Swedish west coast near an oil refinery. According to these ratio values, mussels from other sites in the study have mainly been exposed to PAHs with pyrolytic origin, or from industries, traffic and fuel combustion.

\section{CONCLUSIONS}

The objective of this field study was to characterise PAH tissue levels and their genotoxic effects as seen in DNA adducts in blue mussels (Mytilus spp.) in Nordic coastal areas. Few papers have reported on DNA adduct and PAH levels in blue mussels in the field, especially from these areas, although mussels are important components of the coastal ecosystems and are in many ways ideal bioindicator orga nisms. In this study, mussels were sampled from 22 sites in Iceland, Norway and Sweden that were suspected to have various PAH origins, mixtures and levels, such as harbours of different sizes, industrialised and urban sites, as well as pristine sites for reference. The results revealed that DNA adducts were higher in gills than digestive gland of the mussels at all sites studied. PAH tissue levels and DNA adducts were generally low, indicating low PAH exposure to mussels in the areas studied. Total PAH tissue 
levels correlated well with the DNA adduct levels $\left(r^{2}=0.73\right)$. The PAHs that correlated individually best with DNA adduct levels were phenanthrene $\left(r^{2}=0.78\right)$ and pyrene $\left(r^{2}=0.71\right)$. According to PAH ratio values, the PAH found in the mussel tissues were mainly of pyrolytic origin, but with petrogenic input close to most harbours and the one site studied near an oil refinery.

\section{ACKNOWLEDGEMENTS}

We thank Lise Tveiten at the Norwegian Institute for Water Research for collection of mussels and dissection of tissues for DNA adduct analyses at the Norwegian sampling sites, and Jón Sólmundson and Hjalti Karlsson for assisting with sampling of mussels at Ísafjörður and Ólafsvík in Iceland. We also thank three anonym referees for valuable comments that helped to improve this paper. This project was supported by grants from the Nordic Council of Ministers.

\section{REFERENCES}

Aas, E., Beyer, J., Jonsson, G., Reichert, W.L., \& Andersen, O.K. (2001). Evidence of uptake, biotransformation and DNA binding of polyaromatic hydrocarbons in Atlantic cod and corkwing wrasse caught in the vicinity of an aluminium works. Mar. Environ. Res. 52, 213229.

Akcha, F., Burgeot, T., Venier, P., \& Narbonne, J.F. (1999). Relationship between kinetics of benzo[a]pyrene bioaccumulation and DNA binding in the mussel Mytilus galloprovincialis. Bull. Environ. Contam. Toxicol. 62, 455-462. 
Akcha, F., Izuel, C., Venier, P., Budinzki, H., Burgeot, T., \& Narbonne, J.F. (2000). Enzymatic biomarker measurement and study of DNA adduct formation in benzo[a]pyrenecontaminated mussels, Mytilus galloprovincialis. Aquat. Toxicol. 49, 269- 287.

Baumard, P., Budzinski, H., Garrigues, P., Burgeot, T., Michel, X., \& Bellocq, J. (1999). Polycyclic aromatic hydrocarbon (PAH) burden of mussels (Mytilus sp.) in different marine environments in relation with sediment PAH contamination, and bioavailability. Mar. Environ. Res. 47, 415-439.

Baumard, P., Budzinski H., Michon, Q., Garrigues, P., Burgeot T., \& Bellocq, J. (1998). Origin and bioavailability of PAHs in the Mediterranean sea from mussel and sediment records. Estuarine, Coastal and Shelf Sci. 47, 77-90.

Budzinski, H., Jones, I., Bellocq, J., Pierard, C., \& Garrigues, P. (1997). Evaluation of sediment contamination by polycyclic aromatic hydrocarbons in the Gironde estuary. Mar. Chem. 58, 85-97.

Broman, D., Näf, C., Lundbergh, I., \& Zebuhr, Y. (1990). An In situ study on the distribution, biotransformation and flux of polycyclic aromatic hydrocarbons (PAHs) in an aquatic foodchain (Seston, Mytilus edulis L., Somateria mollissima L.) from the Baltic - An ecotoxicological perspective. Environ. Toxicol. Chem. 9, 429-442.

Canova, S., Degan, P., Peters, L.D., Livingstone, D.R., Voltan, R., \& Venier, P. (1998). Tissue dose, DNA adducts, oxidative DNA damage and CYP1A-immunopositive proteins in mussels exposed to waterborne benzo[a]pyrene. Mutat. Res. 399, 17-30.

Colombo, J.C., Pelletier, E., Brochu, C., Khalil, M., \& Catoggio, J.A.. (1989). Determination of hydrocarbon sources using N-Alkane and polyaromatic hydrocarbon distribution indexes Case-Study - Rio-De-La-Plata Estuary, Argentina. Environ. Sci. \& Technol. 23, 888-894.

Ericson, G., \& Larson, A. (2000). DNA adducts in perch (Perca fluvatilis) living in a coastal water polluted with bleached pulp mill effluents. Ecđox. Environ. Saf. 46, 167-173.

Ericson, G., Lindesjöö, E., \& Balk, L. (1998). DNA adducts and histopahtological lesions in perch (Perca fluvatilis) and northern pike (Esox lucius) along a polycyclic aromatic hydrocarbon gradient on the coastline of the Swedish Baltic Sea. Can. J. Fish. Aquat. Sci. 55, 815-824. 
Ericson, G., Liewenborg, B., Lindesjöö, E., Näf, C., \& Balk, L. (1999). DNA adducts in perch (Perca fluvatilis) from a creosote contaminated site in the River Ångermanälven, Sweden. Aquat. Toxicol. 45, 181-193.

Ericson, G., Skarphedinsdottir, H., Dalla Zuanna, L., \& Svavarsson, J. (2002). DNA adducts as indicators of genotoxic exposure in indigenous and transplanted mussels, Mytilus edulis L. from Icelandic coastal sites. Mutat. Res. 516, 91-99.

Gosling, E.E. (1992). The mussel Mytilus: ecology, physiology, genetics and culture (589 pp). Amsterdam, Elsevier.

Granby, K., \& Spliid, N.H. (1995). Hydrocarbons and organochlorines in common mussels from the Kattegat and the Belts and their relation to condition indexes. Mar. Poll. Bull. 30, 74-82.

Harvey, J.S., \& Parry, J.M. (1997). The detection of genotoxin-induced DNA adducts in the common mussel Mytilus edulis. Mutagen. 12, 153-158.

Harvey, J.S., \& Parry, J.M. (1998). The analysis of DNA adduct formation, removal and persistence in the common mussel Mytilus edulis exposed to 4nitroquinoline 1-oxide. Mutat. Res. 399, 31-42.

Harvey, J.S., Lyons, B.P., Waldock, M., \& Parry, J.M. (1997). The application of the ${ }^{32}$ Ppostlabelling assay to aquatic biomonitoring. Mutat. Res. 378, 77-88.

Harvey, J.S., Lyons, B.P., Page, T.S., Stewart, C., \& Parry, J.M. (1999). An assessment of the genotoxic impact of the Sea Empress oil spill by the measurement of DNA adduct levels in selected invertebrate and vertebrate species. Mutat. Res. 441, 103-115.

Kautsky, N. (1982). Growth and size structure in a Baltic Mytilus edulis population. Mar. Biol. 68,117-133.

Kurelec, B., Garg, A., Kra, S., \& Gupta, R.C. (1990). DNA adducts in marine mussel Mytilus galloprovincialis living in polluted and unpolluted environments. InJ.F. McCarthy, \& L.R. Shugart, Biomarkers of environmental contamination (pp. 217-227). Boca Raton, FL: Lewis publishers.

Kurelec, B. (1993). The genotoxic disease syndrome. Mar. Environ. Res. 35, 341-348. 
Livingstone, D.R., \& Farrar, S.V. (1984). Tissue and subcellular distribution of enzyme activities of mixed function oxygenase and benzo[a]pyrene metabolism in the common mussel Mytilus edulis L. Sci. Tot. Environ. 39, 209-235.

Lorenz, L.F., \& Glovik, L.R. (1972). Ana lysing creosote by gas chromatography.

Relationship to creosote specifications. Proceedings of the American Wood-Preservers Association 68.

Marsh, J.W., Chipman, J.K., \& Livingstone, D.R. (1993). Formation of DNA adducts following laboratory exposure of the mussel, Mytilus edulis, to xenobiotics. Sci. Tot. Environ. YEAR (Suppl.) 567-572.

Miller E.C. \& Miller J.A. (1981). Mechanisms of chemical carcinogenesis. Cancer, 47, 10551064.

Naes, K., Knutzen, J., \& Berglind, L. (1995). Occurrence of PAH in marine organisms and sediments from smelter discharge in Norway. Sci. Tot. Environ. 163, 93-106.

Neff, J.M. (1979). Polycyclic aromatic hydrocarbons in the aquatic environment (262 pp.). London, England: Applied Science Publishers Ltd.

Pecseli, M., Pritzl, G., Thomsen, M., Asmund, G., \& Christensen, J.T. (2002). Polycyclic aromatic compounds in the Greenland marine environment. Polycyclic Aromatic Compounds 22, 689-702.

Porte, C., Biosca, X., Sole, M., \& Albaiges, J. (2001). The integrated use of chemical analysis, cytochrome $\mathrm{P} 450$ and stress proteins in mussels to assess pollution along the Galician coast (NW Spain). Environ. Poll. 112, 261-268.

Potrykus, J., Albalat, A., Pempkowiak, J., \& Porte, C. (2003). Content and pattern of organic pollutants (PAHs, PCBs and DDT) in blue mussels (Mytilus trossulus) from the southern Baltic Sea. Oceanologia 45, 337-355.

Reddy, M.V. \& Randerath, K. (1986). Nuclease P1-mediated enhancement of sensitivity of ${ }^{32} \mathrm{P}$-postlabeling test for structurally diverse DNA adducts. Carcinogenesis 7, 1543-1551. 
Reichert, W.L. \& French, B. (1994). The ${ }^{32}$ P-postlabeling protocols for assaying levels of hydrophobic DNA adducts in fish. NOAA Tech. Memo (89 pp.). NMFS-NWFSC-14, National Technical Information Service, Springfield, VA.

Reichert, W.L., Myers, M.S., Peck-Miller, K., French, B.F., Anulacion, B.F., Collier, T.K., Stein, J.E., \& Varanasi, U. (1998). Molecular epizootiology of genotoxic events in marine fish: Linking contaminant exposure, DNA damage, and tissue level alterations. Mutat. Res. 411, 215-225.

Riginos, C. \& Cunningham, W. (2005). Local adaptation and species segregation in two mussel (Mytilus edulis x Mytilus trossulus) hybrid zones. Molecular Ecology 14, 381-400.

Shugart, L.R. (1995). Environmental genotoxicology. InG. M. Rand, Aquatic toxicology. Effects, environme ntal fate, and risk assessment (pp. 405-419). North Palm Beach. Florida: Taylor and Francis.

Skarphedinsdottir, H., Ericson, G., Dalla-Zuanna, L., \& Gilek, M. (2003). Tissue differences, dose-response relationship and persistence of DNA adducts in blue mussels (Mytilus edulis) exposed to benzo[a]pyrene. Aquat. Toxicol. 62, 165-177.

Skarphedinsdottir, H., Ericson, G., Halldorsson, H.P., \& Svavarsson, J. (2005). Seasonal and intertidal impact on DNA adduct levels in gills of blue mussels (M. edulis L.). Environ. Poll. $136,1-9$.

Soclo, H.H., Garrigues, P., \& Ewald, M. (2000). Origin of polycyclic aromatic hydrocarbons (PAHs) in coastal marine sediments: Case studies in Cotonou (Benin) and Aquitaine (France) areas. Mar. Poll. Bull. 40, 387-396.

Solé, M. (2000). Assessment of the results of chemical analyses combined with the biological effects of orga nic pollution on mussels. Trend. Anal. Chem. 19, 1-9.

Solé, M., Porte, C., Biosca, X., Mitchelmore, C.L., Chipman, J.K., Livingstone, D.R., \& Albaigés, J. (1996). Effects of the "Agean Sea" oil spill on biotransformation enzymes, oxidative stress and DNA-adducts in digestive gland of the mussel (Mytilus edulis L.). Biochem. Physiol. 113C, 257-265. 
Stein, J.E., Collier, T.K., Reichert, W.L., Casillas, E. Hom, T., Varanasi, U. (1993).

Bioindicators of Contaminant Exposure and Sublethal Effects in Benthic Fish from Puget Sound, Usa. Mar. Environ. Res. 35, 95-100.

Stephensen, E., Svavarsson, J., Sturve, J., Ericson, G., Adolfsson-Erici, M., \& Forlin, L. (2000). Biochemical indicators of pollution exposure in shorthorn sculpin (Myoxocephalus scorpius), caught in four harbours on the southwest coast of Iceland. Aquat. Toxicol. 48, 431442.

Venier, P., \& Canova, S. (1996). Formation of DNA adducts in the gill tissue of Mytilus galloprovincialis treated with benzo[a]pyrene. Aquat. Toxicol. 34, 119-133.

Venier, P., Canova, S., \& Levis, A.G. (1996). DNA adducts in Mytilus galloprovincialis and Zosterisessor ophiocephalus collected from PAC-polluted and reference sites of the Venice lagoon. Polycyclic Aromatic Compounds 11, 67-73.

Webster, L., McIntosh, A.D., Dalgarno, E.J., Megginson, C., Shepherd, N.J., \& Moffat, C,F. (2003). The polycyclic aromatic hydrocarbon composition of mussels (Mytilus edulis) from Scottish coastal waters. J. Environ. Monit. 5, 150-159. 
Table 1. Description of the sampling sites, pollution sources at the sites, size of sampled mussels, average DNA adduct levels in gills of the mussels, PAH whole mussel tissue levels, and PAH ratio values of phenanthrene/ anthracene and fluorene/pyrene

\begin{tabular}{|c|c|c|c|c|c|c|c|c|}
\hline $\begin{array}{c}\text { Site } \\
\text { no. }\end{array}$ & Coastal area & Samplingstation & Expected pollution source & $\begin{array}{c}\text { Mussel size } \\
\text { mm } \\
\text { average } \pm \text { stdev }\end{array}$ & $\begin{array}{l}\text { DNA adducts } \\
\text { (nmol/mol } \\
\text { norm. nucl.) }\end{array}$ & $\begin{array}{l}\text { Sum PAH } \\
\text { ng/g dry wt } \\
\text { (ng/g wet wt) }\end{array}$ & $\mathbf{P h} / \mathbf{A n}$ & $\mathbf{F l} / \mathbf{P y}$ \\
\hline 1 & Iceland & Hvalfjörður (reference) & Remote, no site specific source & $48.8 \pm 3.0$ & 0.53 & $240(35)$ & 5.8 & 1.4 \\
\hline 2 & Iceland & Ísafjörður & Small fishing harbour & $45.1 \pm 5.2$ & 1.50 & $230(20)$ & 6.6 & 0.7 \\
\hline 3 & Iceland & Ólafsvík & Small fishing harbour & $53.5 \pm 5.0$ & 2.10 & $10830(1559)$ & 3.9 & 0.2 \\
\hline 4 & Iceland & Grafarvogur & Urbanised, $5 \mathrm{~km}$ from cargo harbour & $44.1 \pm 3.4$ & 3.00 & $560(73)$ & 4.2 & 0.5 \\
\hline 5 & Iceland & Reykjavík harbour & Harbour, urbanised & $43.4 \pm 4.0$ & 10.00 & $11670(1891)$ & 5.6 & 0.7 \\
\hline 6 & Iceland & Keflavík & Small fishing harbour & $49.5 \pm 4.4$ & 1.90 & n.a. & - & - \\
\hline 7 & Iceland & Porlákshöfn & Small fishing harbour & $46.7 \pm 3.9$ & 4.10 & $3520(395)$ & 1.3 & 3.0 \\
\hline 8 & Norway & Valløy (reference) & Remote, no site specific source & $59.4 \pm 4.9$ & 1.20 & $723(103)$ & 10.2 & 1.1 \\
\hline 9 & Norway & Fiskaatangen & Harbour, anode plant for Mn smelters & $55.9 \pm 3.9$ & 10.10 & $5120(574)$ & 6.1 & 1.1 \\
\hline 10 & Norway & Croftholmen & Inner fjord-harbour, Mn smelter & $53.7 \pm 3.6$ & 3.10 & 1315 (119) & 4.8 & 1.1 \\
\hline 11 & Norway & Sauda & Inner fjord/harbour, Mn smelter & $40.7 \pm 4.1$ & 0.91 & $1240(177)$ & 4.1 & 1.7 \\
\hline 12 & Sweden, West coast & Fjällbacka (reference) & Remote, no site specific source & $49.1 \pm 5.2$ & 0.58 & $240(41)$ & 7.5 & 1.4 \\
\hline 13 & Sweden, West coast & Brofjorden & Oil refinery & $48.8 \pm 4.7$ & 1.20 & $370(62)$ & 2.8 & 0.9 \\
\hline 14 & Sweden, West coast & Stenungsund a (Jordh.bukten) & Petrochemical industry & $53.3 \pm 5.5$ & 2.40 & $125(12)$ & 4.0 & 1.5 \\
\hline 15 & Sweden, West coast & Stenungsund b (Almön) & Petrochemical industry & $51.4 \pm 4.7$ & 1.40 & $120(19)$ & 4.9 & 1.2 \\
\hline 16 & Sweden, West coast & Gothenburg a (Nya Varvet) & Urbanised river mouth, harbours & $49.7 \pm 4.1$ & 2.80 & $925(77)$ & 4.5 & 0.9 \\
\hline 17 & Sweden, West coast & Gothenburg b (Sandvik) & Urbanised, small harbour & $52.3 \pm 3.9$ & 2.30 & $660(91)$ & 5.1 & 1.1 \\
\hline 18 & Sweden, Baltic Sea & Askö (reference) & Remote, no site specific source & $24.1 \pm 2.2$ & 0.90 & $40(3)$ & & \\
\hline 19 & Sweden, Baltic Sea & Oxelösund & Steel plant & $22.6 \pm 1.8$ & 2.60 & $1330(105)$ & 5.8 & 1.9 \\
\hline 20 & Sweden, Baltic Sea & Kvädöfjärden & Remote, no site specific source & $26.2 \pm 1.6$ & 3.80 & $100(9)$ & 1.2 & 1.6 \\
\hline 21 & Sweden, Baltic Sea & Svartören & Pulp industry & $27.5 \pm 2.1$ & 1.40 & $320(24)$ & 3.6 & 1.5 \\
\hline 22 & Sweden, Baltic Sea & Svartlingskär & Pulp industry & $24.2 \pm 2.4$ & 3.30 & $220(16)$ & 3.2 & 1.7 \\
\hline
\end{tabular}




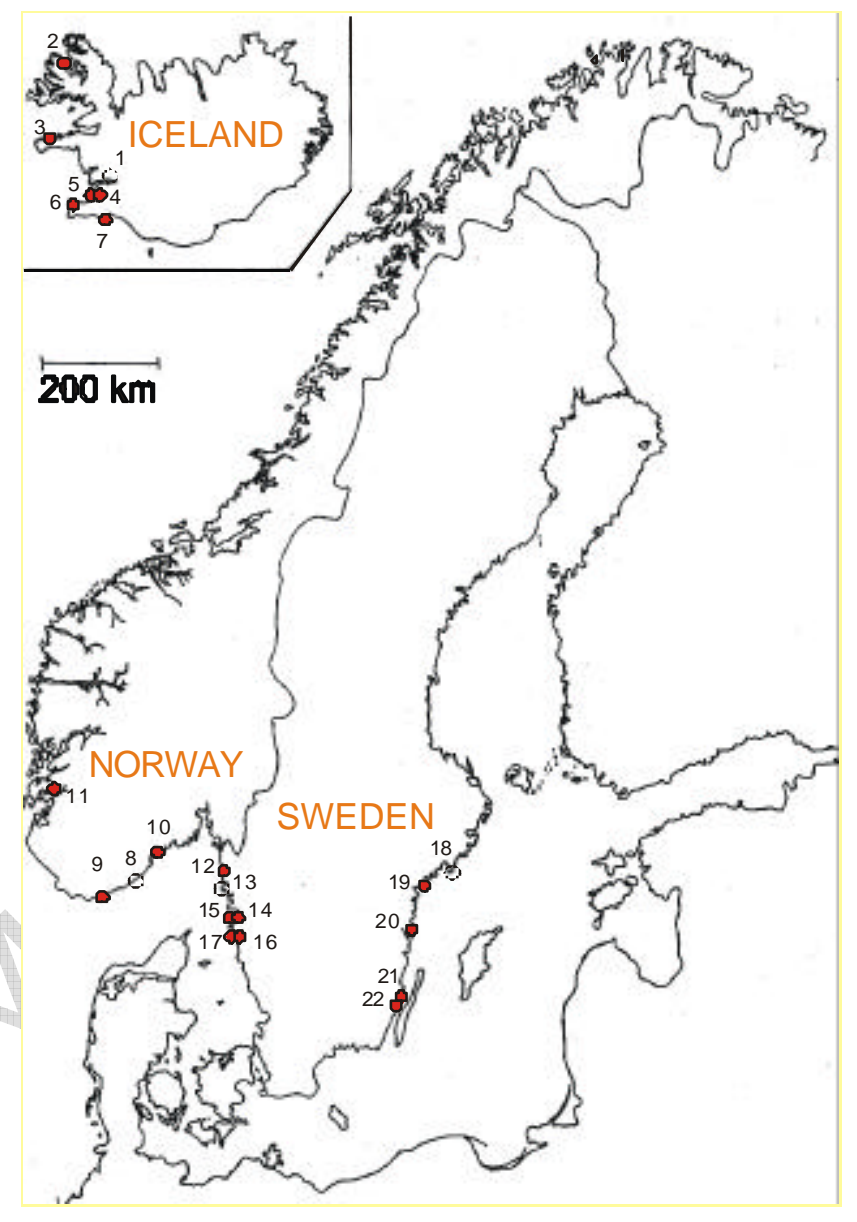

Figure 1. Sampling sites. 


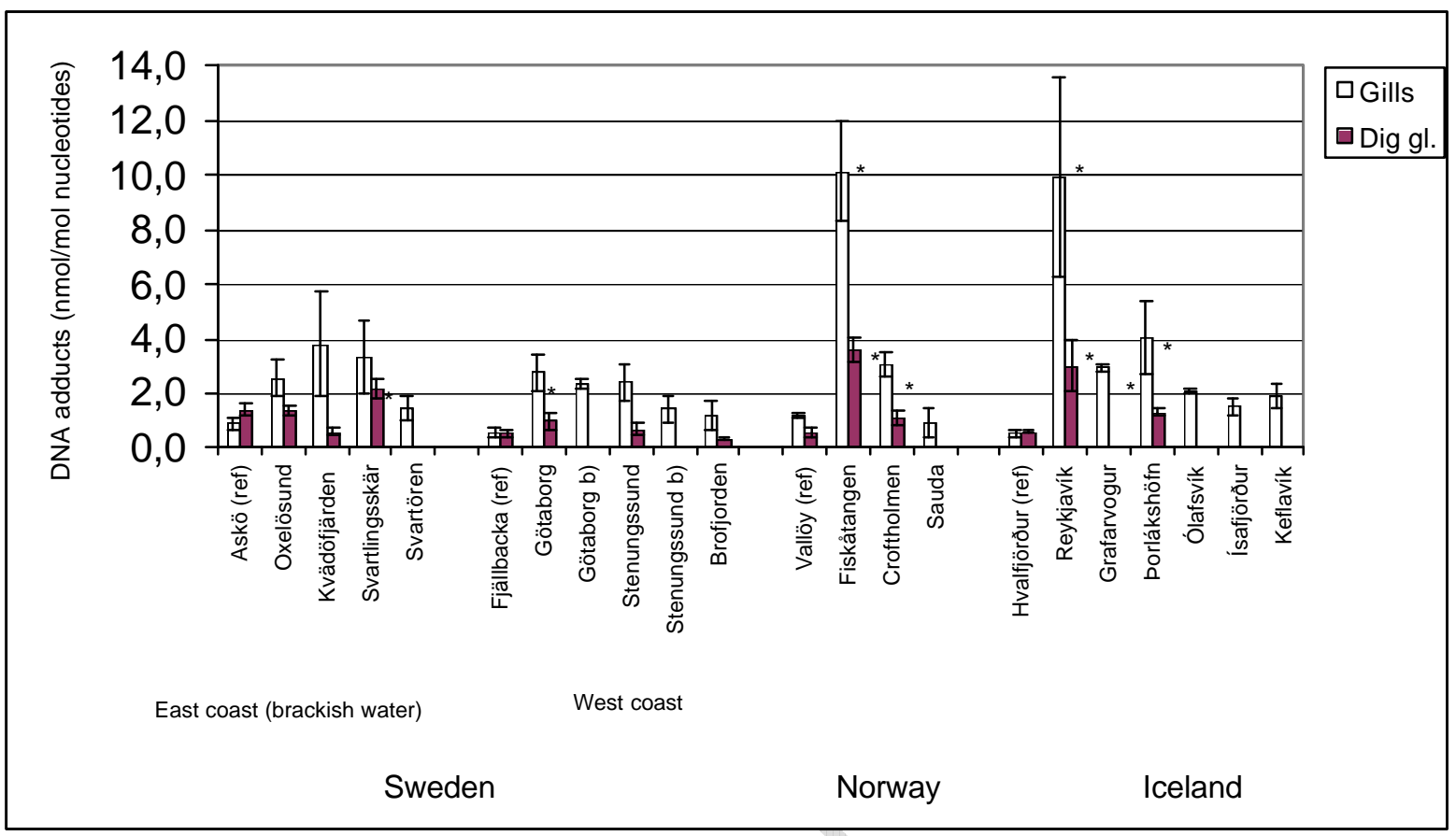

Figure 2. DNA adduct levels in gills and digestive gland of Mytilus spp. in Sweden, Norway and Iceland (mean $+/$ SE, $\mathrm{n}=3-4$ pools of 5 mussels each). $*=P<0.05$, significantly different from respective reference site (which is the first sites/bars in each region). 

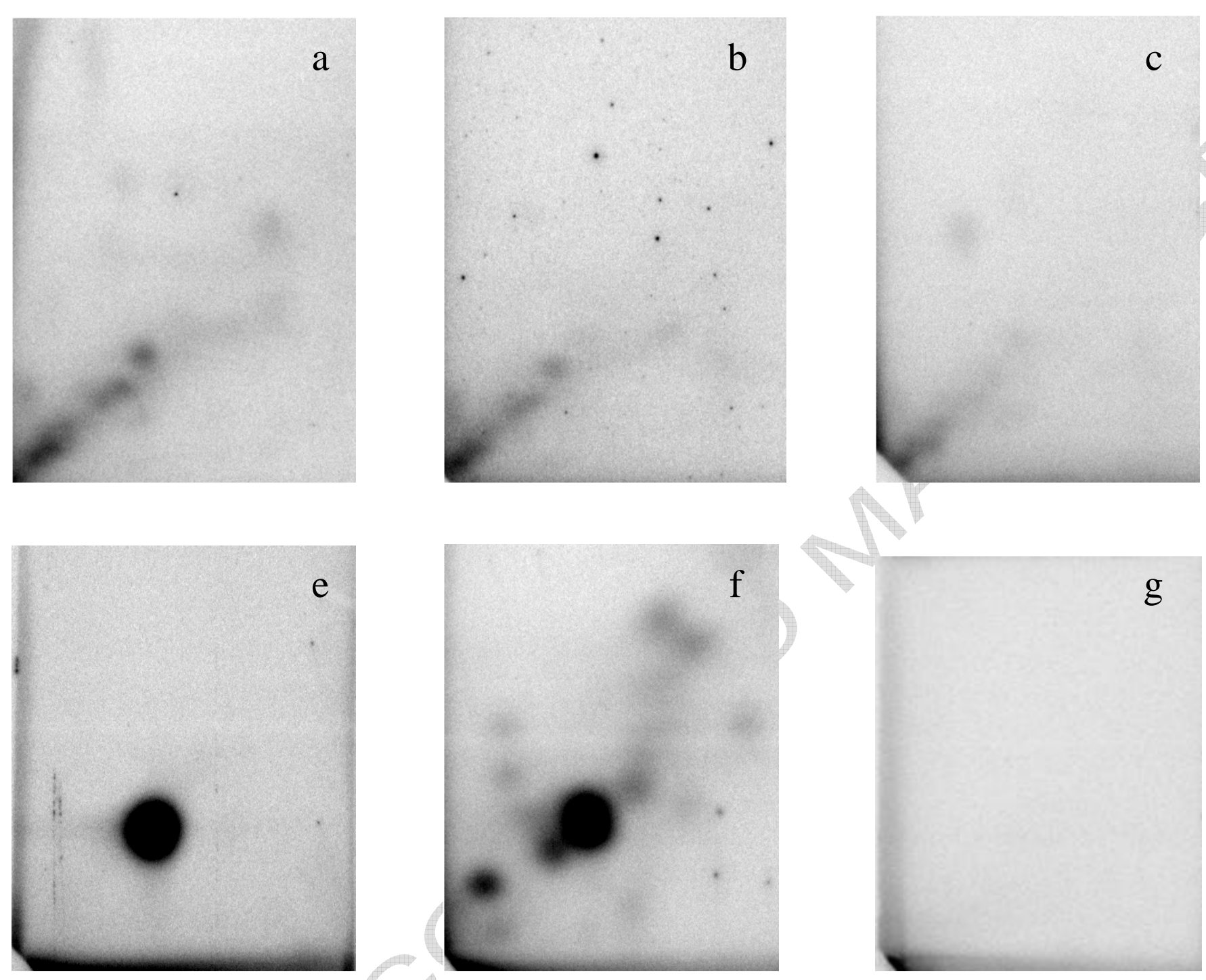

Figure 3. Representative autora diograms of ${ }^{32} \mathrm{P}$-postlabelled DNA adducts in gills of Mytilus edulis from Reykjavík harbour, Iceland (a); Fiskaatangen, Norway (b); Göteborg, west coast of Sweden (c); and Mytilus spp. from Kvädöfjärde n, east coast of Sweden, The Baltic Sea (d); the standard BaP-dG adduct (e); the positive control sample from pearch exposed to benzo[a]pyrene (f); and the negative control of salmon sperm (g). 